\title{
A Study on the Development of English Teachers in Local Universities Based on Educational Informatization
}

\author{
Liping Gao \\ Department of Foreign Language Teaching, Tonghua Normal University, Tonghua, China \\ eyesonme120@126.com
}

\begin{abstract}
Keywords: Development of English teachers; Educational informatization; Information literacy; Role reorientation
\end{abstract}

\begin{abstract}
With the continuous development of information technology in our country, the application of information technology in education has become an inevitable trend. Teachers' information literacy also determines the quality of their teaching. Nowadays, college education is more diversified, and the use of information technology is often involved in the teaching activities. If teacher lacks the proper information literacy, it will inevitably affect the normal development of teaching activities. It becomes more and more important to analyze the present status of information literacy of English teachers in colleges and universities and cultivate ways to improve the information literacy of teachers. Improvement of college English teachers' information literacy will surely improve information technology level. Teachers' new role reorientation will promote career development of teachers. They both will perfect the quality of local education and make contributions to the local construction.
\end{abstract}

\section{Introduction}

As we all know that education makes contribution to the social service, while local colleges and universities contribute to the cultivation of professional graduates for the local construction. In order to meet the high standard needs of professional staff, teaching reform in universities becomes more and more important, English teaching reform is no exception. Especially under the circumstance of educational informatization, the information literacy of teachers will determine the teaching quality and overall school level. However, according to the survey, the current information literacy of English teachers in colleges and universities is generally low, which has seriously affected the quality of teaching. In this regard, it is necessary for educators to enhance their information awareness, improve their own information literacy, and repose the role in the context of informatization to improve the career development planning of teachers[1].

\section{Opportunities and Challenges for Local Universities Under the Background of Educational Informatization}

The advent of the information revolution has affected our higher education. The information technology for education, which has network technology and multimedia technology as the core, brings a new opportunity for the teaching, management and scientific research of local colleges and universities. However, there is imbalanced development of education in China, most of local undergraduate colleges lag behind in network education. Compared with adequate school funding, huge area advantages, and strong faculties in some prestigious universities, lots of local undergraduate colleges encounter difficulties in online practice. They face the reality of limited school funding, poor location and lack of teachers. For example, the insufficient investment in schools, poor hardware and lack of advanced modern multimedia education, the lack of high-quality video and audio equipment and high-quality network teams. Teachers lack of the courage to change and also lack the knowledge accumulation of network teaching. There's so much disadvantages faced by local universities[2].

Despite local undergraduate institutions faced the difficulties by implementing online teaching, the Internet teaching brings the opportunity to reduce the gap with the key universities. 
Therefore, in the process of popularizing online teaching, local undergraduate colleges and universities must take advantage of the local economy to explore and cultivate the key teaching specialty of the school, and fulfill its all-around development.

\section{Current State of Information Literacy of College English Teachers and the Ways of Improvement}

In order to fully understand the present situation of English teachers' educational skills in colleges and universities, and further understand how to promote the development of the language teaching reform, our research team conducted an in-depth survey. The means of investigation include questionnaire, interview and observation. We conducted a questionnaire survey among our university's 50 college English teachers and collected 49 copies of the effective answers. The author analyzes the data obtained:

The Present Situation of English Teachers' Educational Skills in Colleges and Universities. Through the investigation, we get a general picture of the present situation of English teachers' educational skills in colleges and universities. English teachers are able to accept the reform of the new teaching model, but they don't really understand what the educational informatization and educational technology are.

Awareness of information technology survey results show(see table 1) that most English teachers have educational skills consciousness and are willing to add information technology into their teaching, but there are still a lot of teachers think that the requirement of educational informatization is too high. They generally acknowledge the importance of educational technology, but subconsciously reject it[3].

Table 1 A survey on the present situation of English teachers ' educational technology in colleges and universities

\begin{tabular}{|c|c|c|c|c|c|}
\hline Survey result & Contents & and options & & & \\
\hline $\begin{array}{l}\text { Are you interested in } \\
\text { information } \\
\text { technology? }\end{array}$ & $\begin{array}{c}\text { so much } \\
6 \%\end{array}$ & $\begin{array}{l}\text { yes } \\
14 \%\end{array}$ & $\begin{array}{c}\text { a little } \\
45 \%\end{array}$ & $\begin{array}{c}\text { no interest } \\
23 \%\end{array}$ & $\begin{array}{l}\text { no } \\
12 \%\end{array}$ \\
\hline $\begin{array}{l}\text { Can educational skills } \\
\text { improve the English } \\
\text { teachers? }\end{array}$ & $\begin{array}{l}\text { sure } \\
11 \%\end{array}$ & $\begin{array}{l}\text { yes } \\
47 \%\end{array}$ & $\begin{array}{c}\text { not clear } \\
15 \%\end{array}$ & $\begin{array}{c}\text { maybe } \\
18 \%\end{array}$ & $\begin{array}{l}\text { no } \\
9 \%\end{array}$ \\
\hline $\begin{array}{l}\text { Have you ever } \\
\text { applied educational } \\
\text { techniques } \\
\text { teaching }\end{array}$ & $\begin{array}{r}\text { often } \\
26 \%\end{array}$ & $\begin{array}{c}\text { occasional } \\
54 \%\end{array}$ & $\begin{array}{r}\text { never } \\
20 \%\end{array}$ & & \\
\hline $\begin{array}{l}\text { Have you studied } \\
\text { modern educational } \\
\text { techniques }\end{array}$ & $\begin{array}{l}\text { yes } \\
18 \%\end{array}$ & $\begin{array}{l}\text { no } \\
82 \%\end{array}$ & & & \\
\hline $\begin{array}{l}\text { Is it necessary to } \\
\text { learn educational } \\
\text { technology? }\end{array}$ & $\begin{array}{l}\text { very } \\
20 \%\end{array}$ & $\begin{array}{l}\text { yes } \\
53 \%\end{array}$ & $\begin{array}{c}\text { not clear } \\
13 \%\end{array}$ & $\begin{array}{c}\text { a little } \\
7 \%\end{array}$ & $\begin{array}{l}\text { no } \\
7 \%\end{array}$ \\
\hline
\end{tabular}

On the whole, English teachers generally have a positive attitude towards information technology, but the lack knowledge of educational techniques limits their applications in teaching. The whole information technology is low enough[4].

Effective Strategies to Improve the Information Literacy of College English Teachers. First, we should enhance training. Training is the main way to improve the information literacy of college English teachers. Currently, some western countries have developed a new model of information technology training, known as the integration of information technology and teaching. Our country should also study the advanced training thought and training mode in the West, and let teachers practice more at the same time. The training should include the processing of pictures, audio and video, and slide making, not only meet the basic information teaching requirements, but also enable teachers to use information 
equipment for English classroom auxiliary teaching. For those teachers with operational skills who already have such a foundation, should focus on the development and integration of English courses. For example, teachers are taught to create foreign language communication platforms, teach and coach online. Finally, teachers should be trained to master the ability of independent learning, learn from the authoritative experts and scholars in English teaching on the Internet, and improve their own teaching level and cultural literacy[5].

Second, teachers should learn by themselves. In addition to participating in training, teachers can also improve information literacy through independent learning. At present, many domestic scholars think that self-study is the main way for teachers to improve information literacy and the best shortcut. There are many ways to learn on your own, such as reading literature, looking for material, watching instructional videos, attending seminars, etc..At present, there are many websites for English teachers to study information technology and to learn about the effective integration of information technology and English curriculum. Learning on these excellent websites can not only improve teachers 'information literacy, but also gain the experience of peers and learn new trends in foreign language teaching.

Third, practice working in community. Community of practice refers to learning groups formed spontaneously by language teachers. Group members develop themselves by mutual learning, guidance and experience communicating. Even when some team members lose their confidence in learning, they can encourage each other to achieve common development and progress. College English teachers can improve their information literacy by participating in the community of practice.

There are also research projects with study groups. During the process of working together, teachers can improve information literacy by acquiring a great deal of information technology knowledge. To sum up, improving the information literacy of college English teachers is a long-term an difficult task that requires the joint efforts of schools and teachers[6].

In today's information society, it has become a prerequisite for the development and advancement of talents to master information technology. The application of information technology in English teaching in colleges and universities is inevitably the key to the development of education.

\section{The Role Localization and Transformative Development of Local College English Teachers}

The traditional teaching mode is a teaching mode with teachers as the center and books as the main body. The development of educational informatization demands the change of the role of English teachers in colleges and universities. The repositioning of the role of English teachers in local colleges and universities under the background of informatization is of great significance to improve the quality of students, improve the career development of teachers and broaden the thinking patterns of local colleges and universities.

Current Status of Role Localization of Local College English Teachers in China. At present, the main reasons for the bias of the role orientation of English teachers in local colleges and universities are as follows: on the one hand, because each teacher needs to teach a large number of students, teachers will not take the learning and living conditions of each student into account; On the other hand, some new teachers are relatively inexperienced, but the teaching task is too heavy, so that teachers can not guarantee the quality of teaching[7].

Many college English courses are mainly taught in large classes, which causes many problems in college English teaching.

First, because the students' English level is different, it is very difficult for teachers to grasp the students' learning status and characteristics, which makes it hard to teach according to their ability.

Second, because of large class teaching, students can not concentrate for a long time, so as not to guarantee the effect of the lessons.

Third, teachers and students in large classes have less opportunities to exchange ideas and practical practice.

In the information age, education should be more student-centered, and demonstrate individuation in the process of education, to enhance students 'ability to learn independently. 
However, in the present local college English classroom, because of many factors such as classroom form and teaching content, students have little motivation to learn, low interest in learning, and no need to learn English well, lack of motivation to learn English autonomously. So teachers have to carry on 'passive' teaching to students with traditional teaching methods.

A New Role Reorientation of English Teachers in Local Universities in China. Reorientation of teachers' role must be based on existing resources. That means the analysis of the role orientation of English teachers in colleges and universities in China must be based on the development of local English teachers and realize the multi-role orientation.

First, Colleges and universities can practice diversity teaching guidance for college English teachers, and schools make full use of the Internet communication channels within universities to implement comprehensive research on the content of course research for college English teachers. English teachers not only combine teaching content to carry out research and exploration of college English textbooks, but also study the relationship between college students' English learning and other small language learning. English teachers can also be organized to carry out the academic aspect of the expanded research and be provided with a broader concept of subject cognition. By this can further stimulate the in-depth understanding of university teachers in the subject area, and provide a supplementary channel of knowledge for the future work of university teachers. At the same time, based on the existing teaching resources of local colleges and universities, the repositioning of the thinking mode of college English teachers is emphasized. Through the cooperation and communication between teachers and students, teachers can have a better understanding of students 'language thinking patterns and difficulties in using English. Last but not least, to guide our college English teachers to make full use of the limited resources to carry out their own multi-analysis, we must take the teacher's own cultural literacy as the basis for practice. To continuously improve the cultural literacy of college English teachers and stimulate their inner potential. Therefore, college English teachers are not only the guide of students 'knowledge learning, the communicator of learning perplexity, but also the guide of students' values. Only by continuously enriching their own knowledge and character can college teachers adapt to the needs of the new era and play the teachers' guiding role[8].

Modernization of teaching by various means. The efficient promotion of college English teaching in the new era lies in the effective development of college English teaching, which should adopt a diverse and modern information teaching method, enrich the college English teaching class and stimulate the students' enthusiasm for learning. For example, the comprehensive utilization of the platform of college campus learning and microteaching resources provides students with a wider space for language learning. Students are no longer stuck in a certain classroom teaching resources for English teachers. Choosing a suitable English learning method is an important manifestation of the transformation of English teaching to autonomy and informatization.

At the same time, local college and university English teachers adopt a variety of teaching methods, and can also use the campus network to build a wide range of interaction in English, teachers share the relevant English news, radio, etc.. Students can also use this platform to carry out the school other auxiliary learning. For example, using the online English composition correction network, using the FIF cloud learning platform to carry out oral training and testing and other auxiliary teaching. The comprehensive exploration of the diversity of English resources is an effective way to stimulate the diversity of English teaching in colleges and universities. The change of different teaching methods will increase the interaction between English teachers and students, and students' English learning will be more automatic and spatial[9].

In order to reorient the English teachers in local colleges and universities and realize the transformation of college English teachers, the school can optimize from two aspects. First, on the one hand, teachers speed up the promotion of students through the mastery of cultural knowledge, to achieve integration with the society. On the other hand, they can use the establishment of school-enterprise cooperation platform or through the "top internship" means to achieve teachers 'post-employment education. Secondly, the implementation of the post-service training strategy will help to optimize the teacher structure of the existing English teaching. For example, the establishment of an online learning library, the development of English professional lectures, etc. Through the integration 
of domestic and foreign resources, the implementation of free post-service training for English teachers in our school has promoted the improvement of the overall quality of English teachers in our school.

\section{Conclusions}

All in all, it is a long and arduous task to improve the information literacy of local college English teachers and to find the right way to readjust their roles. It needs the joint efforts of both the school and teachers. In today's information society, mastering information technology ability has become a prerequisite for the development and advancement of talents. The application of information technology in college English teaching is an inevitable requirement for education development. Improving the information literacy of English teachers is not only to improve their information technology level, but also to create an efficient and modern English classroom.

\section{Acknowledgements}

This paper is topics of the "13th Five-Year Plan" Project Education Science in Jilin Province for 2016 (GH16345) research results.

\section{References}

[1] Zhian Xie: Research on the Professional Development of English Teachers in Colleges and Universities(Intellectual Property Press, China 2014), p.160-166.

[2] Chuxiong Chen: Journal of Hetian Normal College, Vol.34(2015)No.6, p23-24.

[3] Liping Gao: Modern Communication, Vol.30(2017)No.22, p.41.

[4] Jie Liang: Journal of Heilongjiang College of Education, Vol.35(2016)No.2, p.30-34.

[5] Yulian Hu: Journal of Educational Institute of Jilin Province, Vol.25(2010)No.7, p.59-61.

[6] Hehua Yu: Journal of Heihe University, Vol.27 (2017)No.2, p.110-111.

[7] Liping Gao: Modern Communication, Vol.30(2017)No.24, p.32-33.

[8] Information on http://www.cauledu.caul/doc/InfoLitStandards 2001.doc

[9] Cuiping Yang: Foreign Language World, Vol.26(2006)No.4, p.57-62. 